\title{
Effects of Macroeconomic Factors on Foreign Direct Investment in Kenya
}

\author{
James Karau $^{1^{*}} \quad$ Paul Ng'ang'a ${ }^{2}$ \\ 1.School of Business and Economics, Daystar University, P.O. Box 44400-00100, Nairobi, Kenya \\ 2.Department of Finance, Silentnight Beddings Ltd, P.O. Box 47023-00100, Nairobi, Kenya
}

\begin{abstract}
This study examined the effects of macroeconomic factors on foreign direct investment in Kenya (FDI). The study used four macroeconomic variables namely foreign exchange rates, tax rates, inflation rates, interest rates and balance of payment for the period 1970 to 2010 . The study used a multiple linear regression analysis with the FDI inflows as the dependent variable and the macroeconomic factors as the independent variables. The study found a positive relationship between FDI and interest rates as well as balance of payments while inflation and tax rate had negative relationship with FDI. The study recommended that the government should promote a stable macroeconomic environment in the country to enhance FDI.
\end{abstract}

Keywords: Interest rate, Inflation rate, Exchange rate, Tax rate, Balance of Payments, Foreign Direct Investment. DOI: $10.7176 / \mathrm{EJBM} / 11-3-06$

\section{Introduction}

Empirical studies have shown that Foreign Direct Investment (FDI) has had a positive effect on growth in the world economies especially so in Sub-Saharan Africa. FDI inflows positively influence economic growth through technology transfer, human capital formation, enhancing healthy competition, promoting global integration and technology transfer (Kinoshita and Nauro, 2003). Himbara (1994) noted that developing countries are increasingly aware of the role of foreign direct investment as an engine of growth in their economies. Foreign investors can contribute to growth by providing much needed capital and skills, by sharing risks in large projects and by serving as a vehicle for technology transfer. For many developing countries, FDI is a mechanism by which to promote industries in which they have a potential comparative advantage that cannot otherwise be exploited.

According to UNCTAD (2007), the global flows of FDI increased from US\$324 billion in 1995 to US\$1.3 trillion in 2006. Inflows of FDI to developed countries amounted to US\$857 billion in 2006 while rising to a record US\$379 billion for developing countries. The global stock of FDI has thus more than quadrupled from US\$2.76 trillion in 1995 to $\$ 12$ trillion in 2006. Most countries however have been facing a common challenge on how to ensure investment policies are grounded in the overall development strategy and that the policies are coherent and synergetic at both national and International levels to attract considerable FDI (Kinyanjui and Kinuthia, 2010). Kenya, like many other developing and emerging nations, has had a big challenge in attracting and sustaining foreign direct investment at levels that allow domestic investment to take advantage of benefits associated with capital inflows. Over a period of time the Kenyan government had initiated and employed policy incentives in order to encourage FDI inflows into the country. Despite these measures, FDI inflows into the country had continued to be characterized by fluctuations.

Kenya was one of most favoured destinations for FDI in East and Central Africa in 1970s. However over the years, Kenya lost its appeal to foreign firms, a phenomenon that continued till around 2008. Mwega and Ndungu (2002) argued that Macroeconomic constraints arising from the collapse of the IMF's Structural Adjustment Program (SAPs) in 1986, massive destruction of infrastructure due to El Nino rains and weak institutions all contributed to economic stagnation Although Kenya introduced a number of instruments to promote FDI and export oriented industrialization during this period, these efforts did not yield much in terms of attracting more FDI or rather halting the downward trend. Kinyanjui and Kinuthia (2010) noted that this forced Kenya in 2008 to launch vision 2030 with the hope of achieving global competitiveness and prosperity of the nation. According to Kinyanjui and Kinuthia (2010), this initiative has been seen as a renewed commitment to attract FDI and assist in the industrialization process.

After this disappointing period of the 1990s, Kenya resumed the path to rapid economic growth in 2002 through the implementation of the Economic Recovery Strategy paper which was replaced by vision 2030 after it expired in 2007. During this period the government embarked on establishment of free trade zones, improvement of business climate, infrastructure, and development of incentives among other initiatives. These efforts were aimed at building a momentum that could sustain economic growth and promote development. At the centre of these efforts was a commitment to attract FDI which was hoped would assist in the industrialization process (Gachino, 2005).

Blomstrom (1990) indicated that there were worrying signs that the whole of the African continent was being marginalized in the global competition for FDI. FDI flows to Africa had decreased by 6.1 percent annually 
between 1994 and 1997. Since the recent years have seen significant improvements in the conditions governing FDI including, but not limited to, economic reforms, democratization, privatization, greater peace and political stability, these trends raise important questions about foreign investors' attitude towards Africa.

This study, sought to get the effect of taxation rates, inflation rate, balance of payments, interest rates and exchange rates on FDI inflows to Kenya. The specific objectives of the study were; 1) identify the levels of FDI inflows in Kenya and 2) examine the effect of various macroeconomic factors on FDI inflows in Kenya

\subsection{Foreign Direct Investment}

Foreign direct investment (FDI) refers to the inflows of investment to acquire a lasting management interest or effective control $(10 \%$ or more voting power) over an enterprise operating in an economy other that of the investor. International Monetary Fund (1993) defines FDI inflows as the values of inward direct investment made by non-resident investors in the reporting economy, including equity fund, reinvested earnings and intracompany loans, net of repatriation of capital and repayment of loans. According to Ruud (2003), it is the investments by multinationals in foreign controlled corporations such as affiliates or subsidiaries. For the purpose of this study, FDI inflows were taken to be the net total of Equity fund, re-invested earnings and intracompany loan. Equity funds are the ones directly sent by the investors as capital and which becomes part of the long term financing with the expected return being capital gain and or dividends. Re-invested earnings, which are funds which rather than being paid out to the shareholders in form dividends, is re-invested into the business to finance the business venture expansion. Intra-company loans are loans extended to a company or to related companies which are used to finance new ventures or to help in expansion of the business (Josef, 2003).

\subsection{Macroeconomic Factors}

\subsubsection{Taxation Rates}

A tax policy is a choice made by a government as to what taxes to levy, in what amounts, and on whom. Higher tax levels of the host country would be expected to deter potential FDI. Studies by Kemsley (1998) and Billington (1999) found the host country tax rate to be a significant factor in determining FDI inflows while another study by Wheeler and Mody's (1992) found the tax rate of the host country to be insignificant. Earnings by an affiliate in foreign country are ultimately subject to parent and host country taxes regardless of whether it is repatriated or reinvested in the foreign affiliate to generate further earnings (Hartman, 1984). The profit tax rates are used in this study as a proxy for corporate tax rates.

\subsubsection{Inflation Rate}

Inflation is the general increase in price level. It is captured by the Kenya consumer price index (CPI) which measures price changes on a designated basket of basic goods and services. A history of low inflation signals to investors about the commitment and credibility of any government. The higher the level of macro instability, the higher the risk premium on investment and the lower the level of investment. Rogoff and Reinhart (2002), in looking at the role of price stability on FDI in Africa, argued that without macroeconomic stability, the risk of doing business rises drastically. High and unpredictable inflation cripples business planning and checks the development of financial intermediation within the private sector. Inflation in this study is measured by the annual average consumer price index.

\subsubsection{Balance of Payment}

This is the record of all international trade and financial transactions made by country residents. It is influenced by changes in output and fiscal policy. The balance of payment is expected to have a positive influence on FDI inflows.

\subsubsection{Interest Rate}

It is defined as the realized or annualized rate of return on a financial investment. It is mostly influenced by changes in output and monetary policy (Froot, \& Stein, 1991). The higher the domestic interest rate relative to world interest rate the greater the attraction of FDI inflows into a country and vice versa ceteris paribus (Hartman, 1984).

\subsubsection{Exchange Rate}

It is the price of a unit of one nation's currency in terms of a unit of a foreign currency. It was measured by annual average of the official market exchange rate in the national currency per United States dollar (USD). The effect of exchange rates on FDI has been examined both with respect to changes in the bilateral level of the exchange rate between countries and in the volatility of exchange rates. Froot and Stein (1991) noted that the common wisdom was that (expected) changes in the level of the exchange rate would not greatly alter the decision by a firm to invest in a foreign country. In rough terms, while an appreciation of a firm's home country's currency would lower the cost of assets abroad, the (expected) nominal return goes down as well in the home currency, leaving the rate of return identical. According to Blonigen (1997) if FDI by a firm is motivated by acquisition of assets that are transferable within a firm across many markets without a currency transaction, then an exchange rate appreciation of the foreign currency will lower the price of the asset in that foreign 
currency, but will not necessarily lower the nominal returns.

\section{Literature Review}

\subsection{Theoretical Framework}

The study was informed by three theoretical frameworks namely; motivation theory, eclectic approach theory and theory of convergence.

\subsubsection{Motivation Theory}

According to this theory FDI is influenced by both the external and internal environments which determine the motivation which is categorized into macro motivation and micro motivation (Kokko, 2002). Macro motivation is affected by environmental conditions lying outside organization while micro motivation is affected by environmental conditions lying within the organization.

\subsubsection{Eclectic Approach Theory}

This theory asserts that FDI is only attractive if the ownership, location and internalization (OLI) conditions are met. First, there must be an ownership advantage for the multinational compared to ownership by local firms. This may be in form of specific technological or organizational knowledge of the multinational. Potential influence of government policy on the benefits of investing and doing business in a specific host country is also potentially important. In some cases the host government may pose restrictions on the extent and nature of foreign ownership. Such restrictions in effect reduce inflows of inward FDI and in essence the technology that would accompany those inflows. Secondly, it must be advantageous for the multinational companies as well as other investors to produce in the host country if they can benefit from some comparative locational advantage. Finally, it should be attractive to undertake activities within the host countries, rather than buying or leasing them from other firms.

\subsubsection{Theory of Convergence}

This theory argues that inferior economies are likely to grow at a faster rate than richer economies. Eventually all economies will converge in terms of per capita income. Due to diminishing returns especially to capital, developing countries have the potential to develop at a faster rate than developed countries (Baum, 1974). FDI can be considered as effective channel for convergence. FDI enhances technology diffusion which incorporates transfer of capital goods, knowledge and managerial skills. Venables (2000) noted that the foreign involvement tends to hasten diffusion when it is possible to assume that the costs of adapting a technology are smaller for those who are more familiar with how the idea operates in the country of origin of the firm.

\subsection{Empirical Literature Review}

According to Ngowi (2000), FDI inflows to a country depend largely on the prevalence of a certain critical minimum favourable macroeconomic factors. The macroeconomic factors are among the factors that give MNEs the confidence and interest to invest their massive and expensive capital in foreign markets. Among the FDI macroeconomic factors that MNEs look for include economic, political and social stability and rules regulating entry and operations of businesses. Others are standards of treatment of the foreign affiliates, business facilitation (including, inter-alia, investment incentives, market size, growth, structure and accessibility, raw materials, low cost but efficient labour force and physical infrastructure in form of ports, roads, power and telecommunication.

Dunning (1995) suggested that one of the dominant factors influencing foreign direct investment was the growth and size of the host country market in terms of population growth. Loree and Guisinger (1995) studying the macroeconomic factors of foreign direct investment in United States in 1977 and 1982 concluded that variables related to host country policy and infrastructure were significant in the developed countries. Green (1972) found out that the allocation of FDI in United States of America was not affected by political instability in recipient countries and that there was even a positive relationship between investment flow and instability in the recipient countries.

Root and Ahmed (1999) and Schneider and Frey (1986) found statistically significant relationship between foreign direct investment and market demand (as measured by per capital GDP or GNP) and market growth (as measured by the growth rate of GDP or GNP). Schneider and Frey (1986) found out a positive relationship between per capital income and FDI inflows. Thunnell (1977) found out that political events were not directly associated with short- term fluctuations, but only with trend changes in foreign investment flows.

Using time series analysis, Kinaro (2000) found out that FDI in Kenya was determined by economic openness, human capital, real exchange rate, inflation and FDI in the previous periods. Opolot et al. (2008), using panel data for Sub Saharan African countries, including Kenya found that market potential, openness to trade, infrastructure, urbanization and rate of return on investment positively affected foreign direct investment inflows while macroeconomic instability was a disincentive to foreign direct investment. Other variables such as government consumption, financial development, natural resources, wage and political rights were found to be insignificant. 
Using panel data of 43 countries with a Kenyan dummy, Mwega and Ngugi (2007) found out that Kenya was not different from other countries and that FDI was determined by economic growth rates, terms of trade shocks, external debt ratio and quality of institutions. UNCTAD (2005) argued that Kenya's inability to attract FDI was due to growing problems of corruption and governance, inconsistencies in economic policies and structural reforms, deteriorating public service and poor infrastructure.

\subsection{Conceptual Framework}

The conceptual framework illustrates that there is a relationship between the macroeconomic variables and FDI inflows.

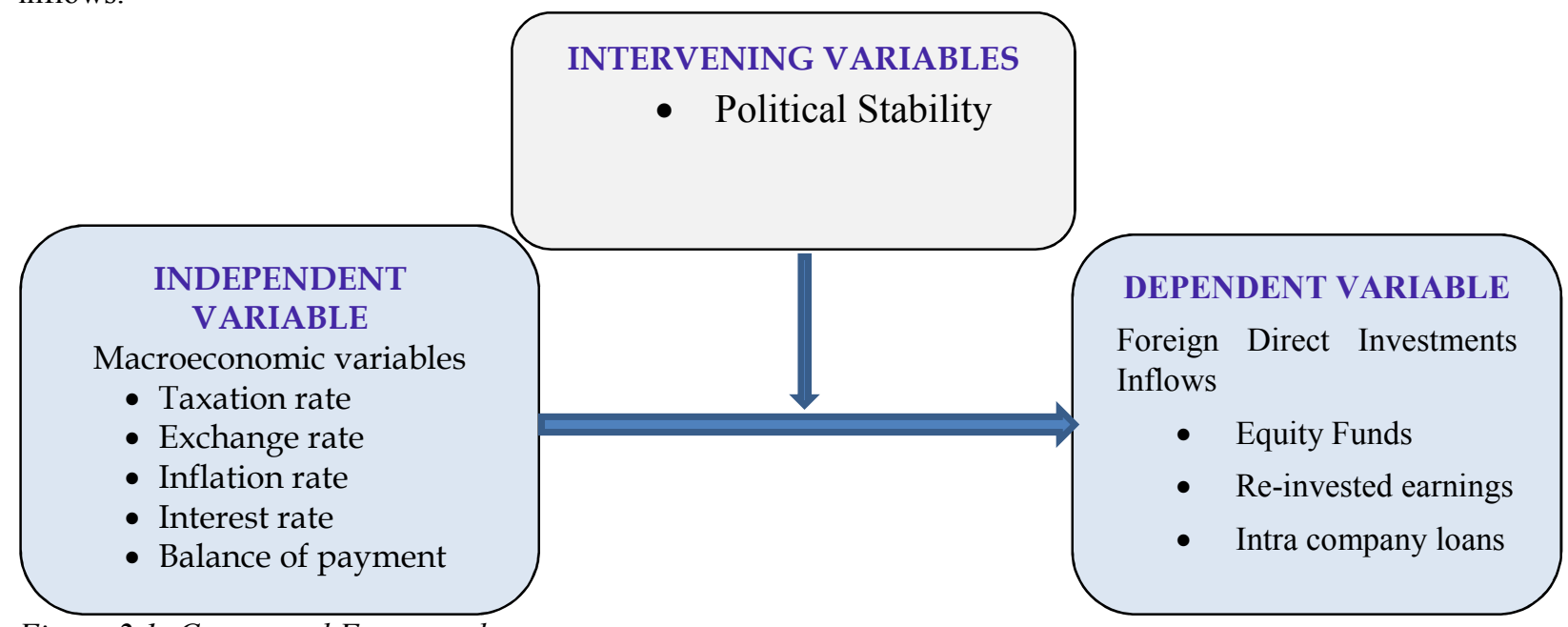

Figure 2.1: Conceptual Framework

Source: Author (2016)

In this study as illustrated in the figure 2.1 , the dependent variable is foreign direct investment inflow, measured in terms of three components namely equity funds directly sent by the investors as capital, re-invested earnings and intra-company loans. The independent variables comprise of taxation rates, inflation rate, balance of payment, interest rates and exchange rates. The intervening variable that was likely to alter the effects of the macroeconomic factors on FDI was political stability.

\section{Research Methodology}

The study considered the FDI inflows and the four financial macroeconomic factors for Kenya for the period between 1970 and 2010. The annual values of Foreign Direct Investment in Kenya at current US Dollar rates; the annual average values of exchange rates as given by the IMF price-adjusted rates of exchange (PARE); corporate tax rates; inflation rates; annual values of imports and exports for the 40 years were used for the analysis.

A multiple regression analysis was conducted to test the influence of the predictor variables. The study used regression analysis model in which the dependent variable was the percentage annual percentage change in FDI inflows to Kenyans and the independent variables were exchange rates, taxes, inflation, and balance of payment. The multiple regression analysis was used to determine how each of the dependent variables relates to annual FDI rates.

The regression model that was estimated was defined as follows:

$¥=\Omega+\beta_{1} X_{1}+\beta_{2} X_{2}+\beta_{3} X_{3}+\beta_{4} X_{4}+\beta_{5} X_{5}$

where:

$¥ \quad=$ annual percentage change in FDI, that is, year $\mathrm{n}$ to year $\mathrm{n}+1$

$\Omega \quad=$ the constant rate of regression

$\mathrm{B}_{\mathrm{i}} \quad=$ the rate of change of FDI inflows due to a unit change in independent variable ${ }_{\mathrm{i}}$

$\mathrm{X}_{1} \quad=$ annual inflation rate

$\mathrm{X}_{2} \quad=$ corporate taxation rate

$\mathrm{X}_{3} \quad=$ annual Interest Rates

$\mathrm{X}_{4} \quad=$ average Annual Exchange Rate

$\mathrm{X}_{5} \quad=$ balance of Payment

\section{Results and Discussion}

\subsection{Levels of FDI Inflows in Kenya}

The study sought to determine the levels of FDI inflows in Kenya. This table presents a summary of the results which is a summary of the FDI inflows by type of investment from 1970 to 2010 for Kenya: 
Table 4.1: FDI Inflows in Kenya, by Type of Investment, 1970-2010

\begin{tabular}{lcrr}
\hline & Equity Funds & Reinvested earnings & Intra company loans \\
Maximum & 102.46 & 55.47 & 54.70 \\
Minimum & - & - & $(21.20)$ \\
Average & 15.76 & 10.25 & 5.91 \\
\hline Total & 643.58 & 451.99 & 242.49 \\
\hline
\end{tabular}

Source: UNCTAD, FDI/TNC database.

From the results in the table 4.1, it was established that the total FDI inflows into the country was USD $1,338.06$ over the 40 years.

\subsection{Descriptive Statistics}

Table 4.2 shows the range of the independent variables over the period of 40 years with the minimum, maximum and mean of the recorded variable for that period.

Table 4.2: Analysis of Independent variables

\begin{tabular}{lllll}
\hline & $\mathrm{N}$ & Minimum & Maximum & Mean \\
\hline Inflation rate & 40 & $2.90 \%$ & $10.59 \%$ & 6.85 \\
Interest rates & 40 & $6.98 \%$ & $20.09 \%$ & $14.17 \%$ \\
Taxation Rates & 40 & $30 \%$ & $45 \%$ & $37.10 \%$ \\
BOP and Economic Output & 40 & 4,980 & 29,809 & 17,739 \\
Exchange Rates & 40 & 7.02 & 79.47 & 37.69 \\
\hline
\end{tabular}

Table 4.2 indicates that over this period of 40 years, the variation for each of the variable was massive. For instance, exchange rate fluctuated from a low of 7.08 to the dollar to a high of 79.47 to the dollar during the period.

\subsection{Regression Analysis}

A multiple regression analysis was conducted to test the influence of the predictor variables and their effects on foreign direct investment in Kenya. The findings are summarized tables 4.3 and 4.4 below.

Table 4.3: Regression Model Summary

\begin{tabular}{|c|c|c|c|c|c|c|c|}
\hline \multirow[b]{2}{*}{ Model } & \multirow[b]{2}{*}{$\mathrm{R}$} & \multirow[b]{2}{*}{$\begin{array}{l}\mathrm{R} \\
\text { Square }\end{array}$} & \multirow[b]{2}{*}{$\begin{array}{l}\text { Adjusted } \\
\text { R Square }\end{array}$} & \multirow{2}{*}{$\begin{array}{l}\text { Std. Error of } \\
\text { the Estimate }\end{array}$} & \multicolumn{3}{|l|}{ Change Statistics } \\
\hline & & & & & $\begin{array}{l}\mathrm{R} \quad \text { Square } \\
\text { Change }\end{array}$ & F Change & Sig. F Change \\
\hline 1 & $0.851^{\mathrm{a}}$ & 0.724 & 0.711 & 2.0167 & 0.711 & 2.619 & $0.015^{b}$ \\
\hline
\end{tabular}

From the findings in table 4.3 the value of adjusted $\mathrm{R}$ squared was 0.711 implying that $71.1 \%$ of changes in foreign direct investment could be accounted for by changes in taxation rates, inflation rates, balance of payments, interest rates and exchange rates at $95 \%$ confidence interval.

Table 4.4: Regression Model Coefficients

\begin{tabular}{lllllll}
\hline \multirow{2}{*}{ Model } & & \multicolumn{2}{l}{ Unstandardized Coefficients } & Standardized Coefficients & \multirow{2}{*}{$\mathrm{t}$} & \multirow{2}{*}{ Sig. } \\
\cline { 3 - 5 } & & $\mathrm{B}$ & Std. Error & Beta & 4.479 & 0.021 \\
(Constant) & & 0.588 & 0.388 & & -5.23 & 0.024 \\
Inflation rate & $\left(\mathrm{X}_{1}\right)$ & -0.266 & 0.02 & -0.276 & -2.30 & 0.022 \\
Taxation Rates & $\left(\mathrm{X}_{2}\right)$ & -0.316 & 0.041 & -0.453 & 3.459 & 0.041 \\
Interest rates & $\left(\mathrm{X}_{3}\right)$ & 0.050 & 0.929 & 0.755 & -4.173 & 0.025 \\
Exchange Rates & $\left(\mathrm{X}_{4}\right)$ & -0.517 & 0.105 & -1.044 & 0.085 & 0.013 \\
Balance of payment & $\left(\mathrm{X}_{5}\right)$ & 0.011 & 0.133 & 0.013 & & 0.013 \\
\hline
\end{tabular}

The regression equation was estimated as follows:

$\mathrm{Y}=0.588-0.266 \mathrm{X}_{1}-0.316 \mathrm{X}_{2}+0.050 \mathrm{X}_{3}-0.517 \mathrm{X}_{4}+0.011 \mathrm{X}_{5}$

As indicated in the table 4.4, the coefficients of all the five macroeconomic factors are statistically significant at 5\% implying that they indeed determined the FDI inflows into the country. Interest rates and balance of payments have a positive effect on FDI inflows while inflation rates, taxation rates and exchange rates have a negative effect on FDI inflows. Holding the independent variables to a constant zero, FDI would stand at 0.588 , while a unit increase in inflation rate would lead to decrease in FDI by a factor of 0.266 ; a unity increase in taxation rate would lead to a decrease in FDI by a factor of 0.316 ; a unit increase in interest rate would lead to increase in FDI by a factor of 0.050; a unit increase in exchange rates would lead to decrease in FDI by a factor of 0.517 while a unit increase in balance of payment would lead to increase in FDI by a factor of 0.011 .

The findings indicated that over the study period Kenya attracted a total of 643.6 million dollars in Equity FDI, representing $48 \%$ of all the FDI inflows. Re-invested funds accounted for 452 million dollars representing $34 \%$ of the inflows while intra-company loans accounted for 34 million dollars or $18 \%$ of all the FDI inflows. 
In total, there was 1,338.1 million USD over the period of 40 years which was an average of USD 32.6 million USD per year. These findings were similar to those of Muthoga (2003) which indicated an average of 36.4 million USD per year

The study findings showed that $71.1 \%$ changes in FDI could be accounted for by changes in exchange rates, tax rates, inflation rates, Interest rates as well as balance of payment. This finding is collaborated by the finding of Kinyanjui and Kinuthia (2010), who using a multiple regression analysis conducted data and a linear relationship and established that $73.5 \%$ of the variance in FDI inflow could be accounted by the independent variables while $26.5 \%$ remained unexplained.

These findings are in agreement with the findings of Manyanza (2012) whose linear regression results revealed that the exchange rate was the most significant variable in determining FDI inflows in Kenya. He also noted that other significant variables were trade balance, interest rate, openness of the economy and tax rates. His findings also revealed that the trade balance and wage rate had a negative effect on FDI.

According to Kinyanjui and Kinuthia (2010), as inflation goes down more FDI is attracted into the economy. Inflation is used as an indicator for volatility of an economy in relation to consumer prices as well as exchange rates. Foreign investors become confident of a market where there is some consistency therefore high inflation acts as a deterrent to FDI.

\section{Conclusions and Recommendations}

From the findings the study revealed that taxation rates, inflation rate, interest rates, exchange rates and balance of payment significantly influenced foreign direct investment in kenya. Thus the study concluded that these macroeconomic factors were the main factors that affected foreign direct investment in Kenya. The study findings revealed that interest rate and balance of payments positively affected Foreign Direct Investment inflows into Kenya, while exchange rates, taxation rates and inflation affected FDI inflow negatively. This is in agreement with other studies such as Kinyanjui \& Kinuthia (2010). The study recommended that there was need for the government policy makers to design polices aimed at controlling inflation rate, interest rates, tax rates and international trade balances and finance (BOP).

\section{References}

Ahn, S., \& Willett, D. (1998). The effect of inflation exchange rate policies on direct investment to developing countries. International Economic Journal, 12(1), 95-104.

Ajayi, S. (2007). The macroeconomic factors of foreign direct investment: A survey of the evidence in foreign direct investment in Sub-Saharan Africa: origins, targets, effect and potential. African economic research consortium. Boston: P.W.S. Publishing Company.

Akinboade, A., Siebrits, K., \& Roussot, N. (2006). Foreign direct investment in South Africa. Pretoria: Foreign Direct Investment.

Asiedu, E. (2002). Aggressive trade reforms and infrastructure development: a solution to Africa's foreign direct investment woes. Kansas: Mimeo.

Barrell, R., \& Holland, D. (1999). Foreign direct investment in central European manufacturing: Consequences for enterprise restructuring and labour productivity. London: NIESR, mimeo.

Baum, W. (1974). On two types of deviation from the matching law: Bias and under matching. Journal of the Experimental Behavior, 22(1), 231-242.

Bennett, D., \& Green, R. (1972). Political instability as a determinant of direct foreign marketing investment. Journal of Marketing Research 9(2), 182-186.

Billington N. (1999). The location of foreign direct investment: an empirical analysis. Applied Economics, 31(2), $65-76$.

Blomström, M., \& Kokko, O. (1990), Regional integration and foreign direct investment, National Bureau of Economic Research Working, No.6019.

Borensztein, E,. \& JW Lee. (1998). How foreign direct investment affect economic growth. (1997). Journal of International Economics, 45(1), 115-135.

Buckley, J., Clegg, J., Wang, C., \& Cross, A. (2002). FDI, regional differences and economic growth: Panel data evidence from China. Transnational Corporation, 11, 1-23.

Campos, N., \& Kinoshita, Y. (2002), Foreign Direct Investment as Technology Transferred: Some Panel Evidence from the Transition Economies. Boston: William Davidson Working Paper, Number 438.

De Mooij, Ruud A., \& Ederveen, S. (2003). Taxation and foreign direct investment: A synthesis of empirical research. International tax and public finance, 10(6), 673-693.

Denzin, N., \& Lincolin, Y. (1994). Handbook of Qualitative Research. London: Thousand Oaks Sage.

Dunning, J. (1993). Multinational Enterprises and Global Economy. Workingham: Addison Wesley.

Dunning, J. (1995). Multinational enterprises and the global Economy, Workingham: Addison Wesley publishers limited. 
Faeth, I. (2009). Macroeconomic factors of Foreign Direct Investment-A tale of nine theoretical models. Journal of economic survey, 23(1), 165-196.

Froot, K., \& Stein, C., (1991). Exchange rates and foreign direct investment an imperfect capital markets approach. (1991). Quarterly Journal of Economics, 106(4), 119-121.

Fukuyama, F. (1992). Trust: The Social Virtues and the Creation of Prosperity, New York: The Free Press.

Gachino, G. (2005). Foreign direct investment, Spillovers and innovation: The case of Kenyan manufacturing industry. (Unpublished doctoral Thesis), University of Ghana, Legon.

Gachino G. (2006). Labour productivity, exports and skills formation: Comparing foreign and local firms in Kenyan manufacturing. Paper presented at the International Workshop FDI-Assisted Development, Oslo.

Hale, G., \& Cheryl L. (2007). Are there productivity spill-overs from foreign direct investment in China? Federal reserve bank of san francisco Working paper series.

Hanson, G., \& Mataloni, C. (2004). "Should countries promote foreign direct investment?” G-24 Discussion Paper Series, no 9.

Hartman, G. (1984). Tax Policy and Foreign Direct Investment in the United States, National Tax Journal. Journal of Public Economics, 26(1), 107-121.

Hayami, Y. (2001). Development economics: from the poverty to the wealth of nations. Oxford: Oxford University Press.

Himbara, S. (1994). The failed Africanization of commerce industry in Kenya. Wold Development, 12(2), 469482.

Holland J. L., Powell, B., \& Fritzsche, A. (2000). Impact of Market size on FDI choices: ( $3^{\text {rd }}$ ed.).

IMF, (2003). Organisation for economic co-operation and development, foreign direct investment statistics: how countries measure FDI, Washington: International Monetary Fund.

International Monetary Fund, balance of payment manual, $\left(5^{\text {th }}\right.$ ed.). 1993.

Jenkins, C., \& Lynne T. (2002). Foreign direct investment in South Africa: macroeconomic factors, characteristics and implications for economic growth and poverty alleviation. Oxford: University of Oxford.

Josef C. (2003). The Effects of Transition and Political Instability on Foreign Direct Investment. London: Central Europe and the Balkans.

Kemsley, D. (1998). The effect of taxes on production location. Journal of Accounting Research 36, 321-341.

Kinaro, E. (2000). Macroeconomic factors of foreign direct investment in Kenya. Dakar: Institute African de Development Economique et de planification.

King'ola, K. P. (2011). A time series analysis of foreign direct investment and economic growth: A case study of Nepal. International Journal of Business and Management, 5(2), 144-148.

Kinoshita, Y., \& Nauro F. (2003), Why does FDI go where it goes? new evidence from the transition economies, IMF Working Paper WP/03/228.

Kinuthia, B. (2010) Does foreign direct investment (FDI) accelerate growth? Evidence from Malaysia. Int. J. Liability and Scientific Enquiry, 13, 99-116.

Kinyanjui, J., \& Kinuthia B. (2010). Foreign direct investment and economic growth: A cross country analysis. Global Economy Journal, 5(1), 1-11.

KNBS, (2012). Investment data and review. Nairobi: The society for international development (SID).

Kobrin, T. (2004): How to investigate the effect of foreign direct investment on development, and use the results to guide policy. Paper prepared for the Brookings conference.

Koima, B. (2005). A review of the empirical literature on FDI Macroeconomic factors. Austria: NBER Working Paper, 11299.

Kojima, K. (1978). Direct foreign investment: A Japanese model for multinational business operations. Croomhelm, London: Foreign direct investment.

Kokko, A. (2002). Globalization and FDI incentives. Paper presented at the annual bank conference on development economics in Europe. Oslo: Mimeo.

Loree, W., \& Guisinger, S. (1995). Policy and non-policy macroeconomic factors of US equity foreign direct investment. Journal of business Studies, 26(2), 281-299.

Majeed, T., \& Ahmad, E. (2009). An analysis of host country characteristics that determine FDI in developing countries: recent panel data evidence. (2008). The Lahore Journal of Economics, 14(2), 71-96.

Manyanza, M. (2012). Determinants of foreign direct investment in Kenya. (Unpublished doctoral thesis), Kenyatta University.

Mayne, K. (1997). The OECD multilateral agreement on investment (MAI). Oxfam United Kingdom.

Mencinger, J. (2003). Does foreign direct investment always enhance economic growth?. Kyklos, 56(4), 491-508.

Miles, B., \& Huberman, A. (1994). Qualitative data analysis: An expanded sourcebook" (2 ${ }^{\text {nd }}$ ed.). California, Beverley Hills: Sage.

Moran, H. (1998). Foreign direct investment and development. The new policy agenda for developing countries and economies in transition. Washington, DC: Institute for International Economics. 
Munyoki, A. (2009). Openness and growth: A time-series, cross-country analysis for developing countries. (2008). Journal of Development Economics, 48, 419-447.

Mwega, F., \& Ndung'u, N. (2002). Draft final report prepared for the AERC collaborative project on explaining African Economic Performance. New York: Investment Forum.

Mwega, F., \& Ngugi, R. (2007). Foreign Direct Investment in Sub Saharan Africa. New York: Africa Economic Research Consortium.

Ngowi, H. (2000). FDI Macroeconomic factors: Can sub-Sahara Africa Increase its Global FDI share? Institute for International Economics.

Ngowi, H. (2000). Tax Incentives for F.D.I.: Types and who should/ should not qualify in Tanzania, The Tanzanet Journal, 1(1), 100-116.

OECD, (2000) International direct investment statistics Yearbook 1999, OECD, Paris: The state printing division office.

Opolot M., \& Kalio, A. (2008). Macroeconomic factors of foreign direct investment: evidence from sub-Saharan Africa using a generalized method of moments dynamic panel estimator. Washington: Macroeconomic Factors.

Opolot, M., \& Mutenyo, J. (2008). Macroeconomic factors of foreign direct investment. Kampala: Research Bank of Uganda.

Rasiah, E., \& Gachino, M. (2005). Does inward foreign direct investment boost the productivity of domestic firms? Review of Economics and Statistics, 89(3), 482-496.

Rogoff, K., \& Reinhart, C. (1996). FD1 to Africa: The Role of price stability and currency instability, Paris: IMF.

Root, Q., \& Ahmed A. (1999). The new global economy and developing countries: making openness work.". Baltimore, ND: Policy Essay No. 24.

Ruud A. (2003). Taxation and foreign direct investment: A synthesis of empirical research, International Tax and Public Finance, 10(6), 673-693.

Sa'nchez-Robles, B., (1996). Infrastructure investment and growth: some empirical evidence. Contemporary Economic Policy, 16, 98-109.

Schneider, F., \& Frey, B. (1986), Economic and Political Macroeconomic factors of Foreign Direct Investment. World Development, 13(2), 161-175.

Taylor, M. (1998). On the Costs of Inward-Looking Development: Price Distortions, Growth and Divergence in Latin America. The Journal of Economic History, 58(1), 19-21.

Thunnell, H. (1977). Political Risk in International Business. NY: Praeger.

UNCTAD. (2007). World investment reports. New York and Geneva: United Nations Conference for Trade and Development.

UNCTAD. (2010). World investment reports 2010. New York and Geneva: United Nations Conference for Trade and Development.

UNCTAD. (2011). World investment reports 2011. New York and Geneva: United Nations Conference for Trade and Development.

UNCTAD. (2005). Investment policy review. New York: UNCTAD.

UNCTAD. (2009). World investment report: transnational corporation and infrastructure challenge. New York: UNCTAD.

Venables, A. (2000, July 18). Gainers and losers from regional integration agreements. Foreing direct investments, Retrieved from http://www.econ.lse.ac.uk/staff/ajv/jpap4.pdf

Wacziarg, R. (2001). Measuring the dynamic gains from trade. World Bank Economic Review, 15(1), 393-429.

Wheeler, D., \& Mody, A. (1992). International investment location decisions: the case of U.S. firms. (1991). Journal of International Economics 33, 57-76.

World Bank. (2000). World development report: Attacking Poverty. Washington, D.C.: World Bank. 